\title{
Kualitas minuman serbuk instan sereh (Cymbopogon citratus) dengan metode foam mat drying
}

The quality of drinks powders instant lemongrass (Cymbopogon citratus) with method foam mat drying

\author{
Deny Utomo ${ }^{1)^{*},}$, Septiani Budi Ariska ${ }^{1)}$ \\ ${ }^{1}$ Program Studi Ilmu Teknologi Pangan, Fakultas Pertanian, Universitas Yudharta Pasuruan \\ *email: denyut369@gmail.com
}

Informasi Artikel:

Dikirim: 01/03/2020; ditinjau: 02/03/2020; disetujui: 25/03/2020

\begin{abstract}
Lemongrass is still limited in use, namely more often for cooking ingredients. Lemongrass contains bioactive compounds that are beneficial to the body. This study aims to determine the quality of instant lemongrass powder drink with foam mat drying method. The method used in the study of instant lemongrass powder is the experimental design used was a factorial randomized block design (RAK) consisting of 2 factors, namely the concentration of maltodextrin $(15 \%, 20 \%$, and 30\%) and the concentration of Tween $80(0.3 \%$ and $0,4 \%)$ so we get 6 treatment combinations. Each treatment was carried out 5 repetitions so that 30 trials were obtained. The tests included physicochemical (antioxidant, water content test, total dissolved solids, color test) and organoleptic tests (color, aroma, and taste). Data analysis was carried out using ANOVA. If significantly different, then proceed by using the Least Significant Difference test (BNT), organoleptic test using Friedman and to find the best treatment. The best results were found in the treatment of maltodextrin percentage $15 \%$ and tween $0.3 \%$ details of the results as follows: characteristics as follows color 3.04 (neutral / ordinary), aroma 3.6 (neutral / ordinary) and taste 4.12 (neutral / normal).
\end{abstract} Keywords: lemongrass, maltodextrin, tween80, instant drinks.

\begin{abstract}
ABSTRAK
Sereh masih terbatas penggunaannya yaitu lebih sering untuk bahan masakan. Serai menggandung senyawa bioaktif yang bermanfaat bagi tubuh. Penelitian ini bertujuan untuk mengetahui kualitas minuman serbuk instan sereh dengan metode foam mat drying. Metode yang digunakan dalam penelitian serbuk instan sereh yaitu Rancangan percobaan yang digunakan adalah Rancangan Acak Kelompok (RAK) Faktorial yang terdiri dari 2 faktor yaitu konsentrasi maltodekstrin $(15 \%, 20 \%$, dan 30\%) dan konsentrasi Tween80 (0,3\% dan 0,4\%) sehingga didapatkan 6 kombinasi perlakuan. Setiap perlakuan dilakukan 5 kali pengulangan. sehingga diperoleh 30 kali percobaan. Uji yang dilakukan meliputi fisikokimia (antioksidan, uji kadar air, total padatan terlarut, uji warna) dan uji organoleptik (warna, aroma, dan rasa). Analisa data dilakukan secara ANOVA. Jika berbeda nyata, maka dilanjutkan dengan menggunakan uji Beda Nyata Terkecil (BNT), uji organoleptik menggunakan Friedman dan untuk mencari perlakuan terbaik. Hasil penelitian terbaik terdapat pada perlakuan persentase maltodekstrin $15 \%$ dan tween $0,3 \%$ rincian hasil sebagai berikut: karakteristrik sebagai berikut warna 3,04 (netral/biasa), aroma 3,6 (netral/biasa) dan rasa 4,12 (netral/biasa).
\end{abstract} Kata kunci : sereh, maltodekstrin, tween 80 , minuman instan. 


\section{PENDAHULUAN}

Serai merupakan salah satu jenis tanaman obat yang mengandung berbagai senyawa bioaktif yang bermanfaat sebagai antioksidan, anti-diabetes, antiencok, antimalaria, anti-hepatotoxic, anti-obesitas, antihipertensi, dan aromanya mampu mengatasi kecemasan (Olorunnisola, 2014). Metode yang dapat diterapkan untuk memperpanjang umur simpan dan memudahkan penyimpanan produk yakni dengan mengolahnya menjadi minuman serbuk instan (Muchtadi, 2010). Minuman instan berupa bubuk merupakan produk olahan pangan yang berbentuk serbuk, mudah larut di air, praktis dalam penyajian dan memiliki luas permukaan yang besar (Tangkeallo, 2014). Proses pembuatan minuman instan secara umum terdiri dari dua tahapan, yaitu proses ekstraksi dan proses pengeringan atau penguapan (Paramita et al., 2015).

Permasalahan dalam pembuatan serbuk instan adalah hilangnya beberapa zat penting seperti vitamin dan mineral yang hilang akibat proses pengeringan tidak sesuai (Mulyani, 2014). Foam mat drying adalah teknik pengeringan bahan berbentuk cair dan peka terhadap panas melalui teknik pembusaan dengan penambahan zat pembuih. Pengeringan dengan bentuk busa (foam), dapat mempercepat proses penguapan air, dan dilakukan dengan suhu rendah (Asiah, 2012). Kelebihan dalam metode pengeringan busa prosesnya relatif sederhana dan murah, proses pengeringan di suhu $50^{\circ} \mathrm{C}-80^{\circ} \mathrm{C}$ sehingga warna, flavour, vitamin dan zat gizi lain dapat dipertahankan (Mulyani, 2014).

Pada metode foam mat drying harus diperhatikan pertama proses pembuatan foam. foam stabilizer berfungsi untuk mempertahankan konsistensi busa adonan sehingga proses pengeringan akan cepat dan bahan tidak rusak karena pemanasan. Komposisi foam stabilizer sangat mempengaruhi kualitas dan kestabilan foam yang terbentuk (Asiah, 2012). Pengolahan minuman serbuk pada metode foam-mat drying dibutuhkan adanya bahan pengisi (filler) dan bahan pembusa (foaming agent) (Mulyani, 2014).

Bahan pengisi yang sering digunakan pada pembuatan minuman serbuk adalah maltodesktrin. Penambahan maltodekstrin bertujuan untuk melapisi komponen flavour, meningkatkan jumlah total padatan, memperbesar volume, mempercepat proses pengeringan, mencegah kerusakan bahan akibat panas serta meningkatkan daya kelarutan dan sifat organoleptik minuman serbuk kulit buah manggis (Putra, 2013). Bahan penstabil yang akan digunakan dalam penelitian yakni carboxyl methyl cellulose (CMC). Fungsi dasar CMC adalah untuk mengikat air dan memberi kekentalan pada fase cair sehingga dapat menstabilkan komponen lain dan mencegah sineresis. (Pujimulyani, 2009). Bahan pembuih yang digunakan untuk pengolahan buah markisa menjadi serbuk yakni dengan menggunakan tween 80 (Susanti dkk, 2014). Tween 80 digunakan sebagai agen peningkatan larutan (Nurhadi, 2015).

Dari hasil uraian tersebut, diperoleh faktor-faktor yang dapat mempengaruhi hasil pembuatan serbuk instan dengan metode pengeringan busa, yakni konsentrasi foaming agent (tween 80), dan konsentrasi bahan pengisi (maltodekstrin). Oleh sebab itu, perlu dilakukan penelitian lebih lanjut untuk memperoleh formula yang optimum pada pembuatan serbuk instan sereh wangi berpotensi sebagai minuman fungsional serbuk instan yang mengandung antioksidan.

\section{METODE PELAKSANAAN}

Penelitian ini menggunakan rancangan percobaan yang digunakan adalah rancangan acak kelompok (RAK) 2 faktor yaitu konsentrasi maltodekstrin $(15 \%, 20 \%$, dan $30 \%)$ dan konsentrasi tween $(0,3 \%$ dan $0,4 \%$ ) sehingga didapatkan 6 kombinasi perlakuan. Setiap perlakuan dilakukan 5 kali pengulangan. 
Tabel 1 Desain penelitian

\begin{tabular}{cccccc}
\hline \multirow{2}{*}{ Perlakuan } & \multicolumn{5}{c}{ Ulangan } \\
\cline { 2 - 6 } & I & II & III & IV & V \\
\hline A1B1 & U1 & U2 & U3 & U4 & U5 \\
A1B2 & U1 & U2 & U3 & U4 & U5 \\
A2B1 & U1 & U2 & U3 & U4 & U5 \\
A2B2 & U1 & U2 & U3 & U4 & U5 \\
A3B1 & U1 & U2 & U3 & U4 & U5 \\
A3B2 & U1 & U2 & U3 & U4 & U5 \\
\hline
\end{tabular}

Keterangan :

A1B1 $=$ Presentasi maltodekstrin 15\%: Presentasi tween $0,3 \%$ $\mathrm{A} 1 \mathrm{~B} 2=$ Presentasi maltodekstrin $15 \%:$ Presentasi tween $0,4 \%$ A2B1 $=$ Presentasi maltodekstrin 20\% : Presentasi tween $0,3 \%$ A2B2 $=$ Presentasi maltodekstrin $20 \%$ : Presentasi tween $0,4 \%$ $\mathrm{A} 3 \mathrm{~B} 1=$ Presentasi maltodekstrin $30 \%:$ Presentasi tween $0,3 \%$ A3B2 $=$ Presentasi maltodekstrin 30\% : Presentasi tween $0,4 \%$

\section{Bahan}

Bahan yang digunakan dalam pembuatan minuman serbuk instan sereh adalah sereh segar yang diperoleh dari desa Sekarmojo dusun Purwo kecamatan Purwosari Kabupaten Pasuruan, maltodekstrin dan CMC (Carboxyl Methyl Cellulose) dibeli di toko (Gunawan Chandra Jakarta Barat), Tween80 dibeli di toko (Sari Kimia Malang) dan air (Sumur). Sedangkan bahan yang digunakan untuk analisa adalah aquadest, larutan 1,1-Diphenyl-2Picrylhyrazil (DPPH), alkohol.

\section{Alat}

Alat yang digunakan dalam pembuatan minuman instan sereh adalah pisau, timbangan digital (Kabuto), timbangan dapur, blender (Cosmos cb-522), blender kering (Miyako), sendok aluminium, alumunium foil (Klin Pak), gelas ukur, kain saring, saringan, sendok besar, gelas, plastik klip, loyang, oven, panci, dan baskom. Alat yang digunakan dalam analisa adalah Color reader, Oven, refraktometer, buret, gegep, gelas piala (pirex), labu ukur, gelas ukur, kaki tiga, pipet tetes, cawan aluminium, oven, cawan porselen, Erlenmeyer, kertas saring, wadah plastik, kapas, Bunsen, desikator, aluminium foil, tanur, tabung reaksi, petridish, dan lain-lain. Alat yang digunakan untuk keperluan analisis organoleptik minuman instan sereh terdiri dari gelas dan sendok.

\section{Prosedur pengolahan minuman serbuk}

Sereh disortasi dan dicuci untuk membersihkan sereh dari kotoran yang terikut. Sereh ditimbang sebanyak 250 gram. Sereh kemudian dipotong sepanjang $22 \mathrm{~cm}$ lalu dilakukan proses perajangan dengan ukuran $1 \mathrm{cmx} 1 \mathrm{~cm}$ untuk memudahkan proses pemblenderan. Sereh kemudian diblender dengan kecepatan paling tinggi selama \pm 3 menit. Sereh diblanching selama 3 menit dengan suhu $70^{\circ} \mathrm{C}$, kemudian sereh disaring untuk menjadi ekstrak sereh.

Setelah didapatkan filtrat/sari sereh dalam proses penyaringan, langkah selanjutnya yaitu pencampuran sari sereh dengan maltodekstrin sesuai formula yang telah ditetapkan yaitu 15\%, 20\% dan 30\% lalu ditambahkan tween sesuai formula yang telah ditetapkan yaitu $0,3 \%$ dan $0,4 \%$ lalu dilakukan pencampuran menggunakan mixer selama \pm 15 menit sampai busa naik dan stabil setelah itu agar busa stabil ditambahkan CMC 0,3\% lalu dicampurkan dengan menggunakan mixer selama \pm 1 menit.

Proses pengeringannya adalah setelah bahan siap diletakkan di atas Loyang yang telah dilapisi dengan aluminium foil kemudian di keringkan dalam oven dengan suhu $70^{\circ} \mathrm{C}$ (7 atau 8 jam). Hasil dari pengeringan kemudian di blender kering selama \pm 2 menit sehingga dihasilkan serbuk sereh. Proses pengayakan dilakukan untuk memisahkan bubuk sereh yang kasar dan halus. Pengayakan dilakukan dengan cara manual dan dengan menggunakan ayakan.

\section{Analisis data}

Pengumpulan data dilakukan dengan observasi terhadap sifat organoleptik minuman instan sereh kepada 25 panelis tidak terlatih. Sifat organoleptik minuman instan sereh meliputi warna, aroma dan rasa. Analisis data uji organoleptik menggunakan Uji Friedman. Parameter fisik kimia yang diamati yang diamati pada produk minuman sereh adalah aktivitas antioksidan (DPPH), kadar air (AOAC,2005), total padatan terlarut (indeks brix) dan kadar warna (colour reader). Penelitian uji fisikokimia dianalisa dengan uji $\mathrm{F}$ dan jika terdapat perbedaan dianalisa dengan uji Tuckey. Perlakuan terbaik dianalisa menggunakan 
metode indeks efektifitas De Garmo (1984) yang dimodifikasi oleh Susrini (2003).

\section{HASIL DAN PEMBAHASAN}

\section{Analisis kadar antioksidan DPPH}

Berdasarkan hasil analisa antioksidan yang dilakukan pada minuman instan sereh dengan perlakuan maltodekstrin dan tween 80 didapatkan rata-rata kadar antioksidan 2,2905 mg/g sampai 9,3295 mg/g. Data hasil pegujian antioksidan dapat dilihat pada tabel 2. Sereh memiliki senyawa bioaktif seperti antioksidan, senyawa flavonoid dan vitamin C. Senyawa yang ada dalam serai selain flavonoid adalah licochacone A dan licochacone B yang memiliki aktivitas antioksidan yang sama dengan glaberen dan tiga kali lebih aktif dibandingkan dengan vitamin E (Gumilar, 2017).

Tabel 2. Rata-rata kadar antioksidan mg/g

\begin{tabular}{|c|c|}
\hline Perlakuan & $\begin{array}{c}\text { Antioksidan } \\
(\mathrm{mg} / \mathrm{g})\end{array}$ \\
\hline $\begin{array}{c}\text { A1B1 (Maltodektsrin 15\%, } \\
\text { Tween 0,3\%) }\end{array}$ & $2,2905 \mathrm{e}$ \\
\hline $\begin{array}{c}\text { A1B2 (Maltodektsrin } 15 \%, \\
\text { Tween } 0,4 \% \text { ) }\end{array}$ & $4,1345 \mathrm{c}$ \\
\hline $\begin{array}{c}\text { A2B1 (Maltodektsrin 20\%, } \\
\text { Tween } 0,3 \%\end{array}$ & $6,0335 \mathrm{c}$ \\
\hline $\begin{array}{c}\text { A2B2 (Maltodektsrin 20\%, } \\
\text { Tween 0,4\%) }\end{array}$ & $9,3295 \mathrm{a}$ \\
\hline $\begin{array}{c}\text { A3B1 (Maltodektsrin 30\%, } \\
\text { Tween } 0,3 \% \text { ) }\end{array}$ & $6,9275 b$ \\
\hline $\begin{array}{c}\text { A3B2 (Maltodektsrin 30\%, } \\
\text { Tween } 0,4 \% \text { ) }\end{array}$ & $2,458 \mathrm{e}$ \\
\hline
\end{tabular}

Maltodekstrin juga dapat berfungsi untuk melindungi senyawa penting dalam bahan seperti antioksidan karena maltodekstrin mempunyai daya ikat yang kuat terhadap bahan yang disalut (Oktaviana, 2012). Penambahan konsentrasi maltodekstrin yang semakin tinggi menyebabkan terjadinya penurunan kadar aktivitas antioksidan. Hal ini diduga oleh semakin banyaknya total padatan yang terkandung dalam bahan yaitu maltodekstrin sebagai bahan pengisi sehingga aktivitas antioksidan yang terukur semakin sedikit, sehingga dengan semakin meningkatnya total padatan dalam suatu bahan, maka kadar aktivitas antioksidan yang terukur akan semakin kecil (Yuliwaty, 2014). Penambahan tween 80 memiliki fungsi sebagai pembentuk busa. Makin besar konsentrasi tween 80 dalam campuran mengakibatkan koefisien perpindahan panas meningkat. Hasil penelitian menunjukkan bahwa semakin banyak konsentrasi tween 80 mengakibatkan semakin menurunnya aktivitas antioksidan (Susianti,2014).

\section{Analisis kadar air}

Berdasarkan hasil analisa kadar air yang dilakukan pada minuman instan sereh dengan perlakuan maltodekstrin dan tween 80 didapatkan rata-rata kadar air 3,522\% sampai 5,7395. Data hasil pegujian kadar air dapat dilihat pada tabel 3. Perlakuan penambahan proporsi maltodekstrin dan tween 80 mempengaruhi kadar air minuman instan sereh, hal ini dapat dilihat pada tabel semakin banyak maltodekstrin maka semakin tinggi kadar air.

Tabel 3 Rata-rata kadar air (\%)

\begin{tabular}{cc}
\hline Kombinasi perlakuan & $\begin{array}{c}\text { kadar air } \\
(\%)\end{array}$ \\
\hline A1B1 (Maltodektsrin 15\%, & $4,738 \mathrm{~b}$ \\
$\begin{array}{c}\text { Tween 0,3\%) } \\
\text { A1B2 (Maltodektsrin 15\%, } \\
\text { Tween 0,4\%) }\end{array}$ & $4,9125 \mathrm{~b}$ \\
$\begin{array}{c}\text { A2B1 (Maltodektsrin 20\%, } \\
\text { Tween 0,3\% }\end{array}$ & $5,1675 \mathrm{ab}$ \\
A2B2 (Maltodektsrin 20\%, \\
$\begin{array}{c}\text { Tween 0,4\%) } \\
\text { A3B1 (Maltodektsrin 30\%, } \\
\text { Tween 0,3\%) }\end{array}$ & $5,7395 \mathrm{a}$ \\
A3B2 (Maltodektsin 30\%, \\
Tween 0,4\%)
\end{tabular}

Keterangan: Nilai rata-rata yang diikuti oleh huruf yang sama tidak berpengaruh nyata menurut uji Tuckey.

Pengaruh perlakuan penambahan konsentrasi maltodekstrin menyebabkan nilai kadar air produk cenderung meningkat. Diduga adanya penambahan konsentrasi maltodekstrin yang tinggi menyebabkan kadar air meningkat. Hal ini karena sifat dari maltodekstrin yang bersifat higroskopis (kemampuan menyerap air) sehingga kadar air menjadi meningkat seiring dengan penambahan maltodektrin (Yuliwaty, 2014). Perlakuan konsentrasi Tween 80 juga 
memberikan pengaruh yang nyata terhadap kadar air serbuk markisa. Hal ini diduga karena adanya gugus hidroksil yang dimiliki oleh Tween 80 sehingga diduga berpengaruh pada semakin banyak konsentrasi tween 80 yang ditambahkan maka serbuk akan semakin bersifat higroskopis. Apabila serbuk bersifat higroskopis maka kemampuan mengikat gugus $\mathrm{OH}$ dari air juga semakin besar (Susanti, 2014).

\section{Total padatan terlarut (TPT).}

Berdasarkan hasil analisa kadar total padatan terlarut (TPT) yang dilakukan pada minuman instan sereh dengan perlakuan maltodekstrin dan tween 80 didapatkan ratarata kadar TPT 9,15 brix sampai13,5 brix. Data hasil pegujian kadar TPT dapat dilihat pada tabel 4. Total padatan terlarut menunjukkan kandungan bahan-bahan yang terlarut dalam larutan (Farikha, 2013). Nilai total padatan terlarut menunjukkan persen bahan terlarut dalam suatu larutan yang kemudian tetap tinggal sebagai residu hasil penguapan dan pemanasan, umumnya dinyatakan dalam satuan $\%$ gula atau obrix. Komponen yang terkandung terdiri atas komponen-komponen yang larut air seperti glukosa, fruktosa, sukrosa dan protein (Bachtiar, 2013).

Tabel 4. Rata-rata total padatan terlarut (brix)

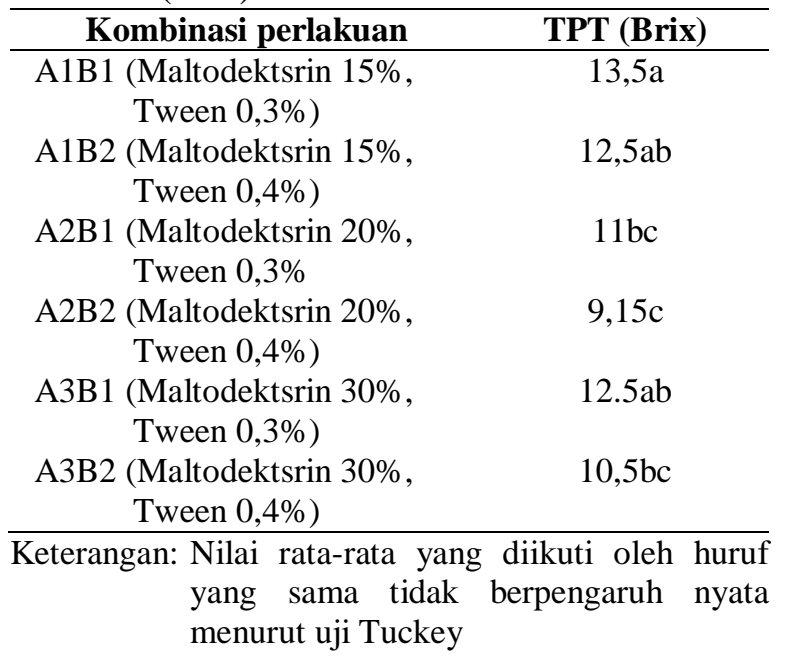

Maltodekstrin merupakan bahan pengisi yang memiliki tingkat kelarutan tinggi, hal ini karena sifat dari maltodekstrin yaitu larut dalam air dan memiliki proses dispersi yang cepat (Ramadhani, 2016). Maltodekstrin juga mengandung gula pereduksi, sehingga semakin banyak maltodekstrin maka nilai total padatan terlarut meningkat (Siagian , 2017). Semakin banyak gugus hidroksil bebas pada bahan pengisi maka semakin tinggi tingkat kelarutannya. Artinya jika nilai kelarutan yang diperoleh semakin tinggi maka menunjukkan semakin baik mutu produk yang dihasilkan, karena proses penyajiannya akan menjadi lebih mudah (Yuliwaty,2014). Semakin tinggi konsentrasi penstabil, semakin tinggi total padatan terlarutnya. Total padatan terlarut meningkat karena air bebas diikat oleh bahan penstabil sehingga konsentrasi bahan yang larut meningkat. Semakin banyak partikel yang terikat oleh bahan penstabil maka total padatan yang terlarut juga akan semakin meningkat dan mengurangi endapan yang terbentuk. Dengan adanya bahan penstabil maka partikelpartikel yang tersuspensi akan terperangkap dalam sistem tersebut dan tidak mengendap oleh pengaruh gaya gravitasi (Kusumah, 2007).

\section{Analisis warna}

Pengujian warna dilakukan dengan menggunakan instrument Color Reader. Hasil pengukuran terbagi menjadi tiga parameter yaitu $\mathrm{L}^{+}$(Lightness), $\mathrm{a}^{+}$(Redness), $\mathrm{b}^{+}$(Yellowness). Hasil pengujian warna minuman instan sereh dapat dilihat pada tabel 5. 
Tabel 5. Rata-rata kadar warna

\begin{tabular}{cccc}
\hline Kombinasi Perlakuan & $\mathbf{L}^{+}$ & $\mathbf{a}^{+}$ & $\mathbf{b}^{+}$ \\
\hline A1B1 (Maltodektsrin 15\%, Tween 0,3\%) & $74,7 \mathrm{c}$ & $6,075 \mathrm{~b}$ & $23,4 \mathrm{~d}$ \\
A1B2 (Maltodektsrin 15\%, Tween 0,4\%) & $75,9 \mathrm{c}$ & $7,875 \mathrm{a}$ & $25,275 \mathrm{c}$ \\
A2B1 (Maltodektsrin 20\%, Tween 0,3\% & $82,8 \mathrm{~b}$ & $6 \mathrm{~b}$ & $27 \mathrm{~b}$ \\
A2B2 (Maltodektsrin 20\%, Tween 0,4\%) & $83,4 \mathrm{~b}$ & $7,8 \mathrm{a}$ & $28,725 \mathrm{a}$ \\
A3B1 (Maltodektsrin 30\%, Tween 0,3\%) & $88,275 \mathrm{a}$ & $4,275 \mathrm{c}$ & $28,65 \mathrm{a}$ \\
A3B2 (Maltodektsrin 30\%, Tween 0,4\%) & $89,775 \mathrm{a}$ & $3,3 \mathrm{c}$ & $26,4 \mathrm{bc}$ \\
\hline
\end{tabular}

Keterangan: Nilai rata-rata yang diikuti oleh huruf yang sama tidak berpengaruh nyata menurut uji Tuckey.

Hasil pengujian warna minuman instan sereh menunjukkan warna merah kekuningan dengan nilai L kisaran antara (74,7-89,775), nilai $\mathrm{a}^{+}(3,3-7,875)$ dan nilai $\mathrm{b}^{+}(23,4-$ 28,725).

Sereh (Cymbopogon citratus) memiliki komponen penyusun yaitu sitronelal, sitronelol dan geraniol (Guenter, 1990). Derajat kecerahan $\mathrm{L}^{+}$perlakuan penambahan maltodekstrin terhadap derajat kecerahan $\left(\mathrm{L}^{+}\right)$mengalami penurunan. Diduga proses pengeringan menyebabkan kerusakan (Utomo, 2013). Warna $\left(\mathrm{L}^{+}\right)$merupakan hasil dari turunan senyawa sitronela yaitu sitronelol yang dapat bertahan selama proses sampai 4jam, jika melebihi kadar 4jam maka kadar dari sitronelol akan turun, hal ini karena bahan yang terlalu panas sehingga menyebabkan kadar sitronelal akan terdekomposisi menjadi senyawa isoterpen (Sebayang, 2014).

Derajat kemerahan $\left(\mathrm{a}^{+}\right)$menunjukkan bahwa perlakuan penambahan maltodekstrin terhadap derajat kemerahan $\left(\mathrm{a}^{+}\right)$mengalami penurunan. Diduga proses pengeringan menyebabkan kerusakan sitronelal yang mengalami reksi oksidasi menyebabkan terjadinya reaksi pencokelatan sehingga derajat kemerahan $\left(\mathrm{a}^{+}\right)$menurun (Utomo, 2013). Warna $\left(\mathrm{a}^{+}\right)$merupakan hasil dari senyawa sitronelal dapat bertahan selama proses sampai 4jam, jika melebihi kadar 4jam maka kadar dari sitronelal akan turun, hal ini karena bahan yang terlalu panas sehingga menyebabkan kadar sitronelal akan terdekomposisi menjadi senyawa isoterpen (Sembahyang, 2014).

Derajat kekuningan $\left(b^{+}\right)$merupakan hasil dari senyawa geraniol. Geraniol dipengaruhi proses sebelum pembuatan ekstrak sereh, setelah ekstrak sereh serta umur tanaman. Perlakuan seperti perajangan sangat mempengaruhi senyawa geraniol. Pada suhu tinggi geraniol akan mudah terpolimerisasi sehingga akan mengurangi total geraniol di samping itu pada suhu tinggi geraniol akan mudah terdekomposisi (Sembahyang, 2014).

\section{Uji organoleptik warna}

Total rengking tingkat kesukaan panelis terhadap warna serbuk instan sereh berkisar antara 1,2 (biasa/netral) - 4,12 (suka). Warna serbuk dengan tingkat kesukaan paling tinggi adalah warna serbuk instan sereh dengan nilai 4,12 pada perlakuan A1B1 . Pada perlakuan A1B1 ini konsentrasi maltodekstrin $15 \%$ dan Konsentrasi tween 0,3\%. Hal ini dikarenakan warna sereh sama dengan ekstrak sereh yaitu kecokelatan sedangkan penambahan maltodekstrin yang semakin banyak menyebabkan warnanya semakin pucat.

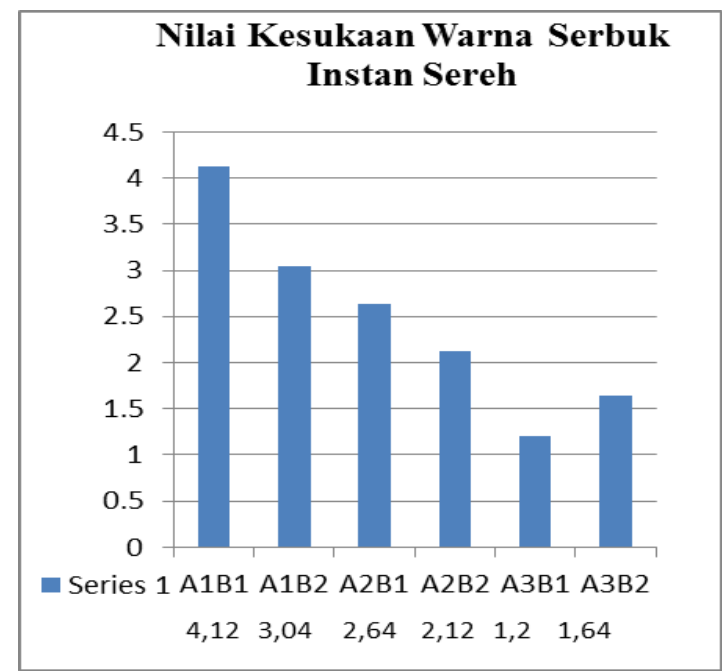

Gambar 1. Grafik tingkat kesukaan panelis terhadap warna minuman sereh

Tingkat kesukaan terendah terhadap warna serbuk instan sereh adalah pada perlakuan A3B1 yaitu dengan konsentrasi 
maltodekstrin $30 \%$ dan dengan konsentrasi tween $0,3 \%$. Hal ini dikarenakan terlalu tinggi kandungan maltodekstrin membuat warna semakin pucat

Warna serbuk dengan tingkat kesukaan paling tinggi adalah warna serbuk instan sereh dengan nilai 4,12 pada perlakuan A1B1 . Pada perlakuan A1B1 ini konsentrasi maltodekstrin $15 \%$ dan Konsentrasi tween 0,3\%. Penggunaan maltodekstrin sebanyak 30\% dengan lama pengeringan yang panjang menghasilkan warna serbuk yang cokelat. Pada sample dengan kode A3B1 dan A3B2 menggunakan maltodekstrin $30 \%$ membuat panelis kurang begitu menyukai karena warna yang ditampilkan kurang menarik yaitu berwarna cokelat pudar.

\section{UJI organoleptik aroma}

Tingkat kesukaan panelis terhadap aroma minuman dari serbuk instan sereh berkisar antara 2,6 (tidak suka) dan 3,6 (Suka). Tingkat kesukaan terendah oleh panelis diberikan pada minuman serbuk instan sereh dengan konsentrasi maltodekstrin $15 \%$ dan konsentrasi tween $0,3 \%$. Tingkat kesukaan tertinggi oleh panelis diberikan pada minuman serbuk instan sereh dengan konsentrasi maltodekstrin $15 \%$ dan konsentrasi tween $0,4 \%$. Konsentrasi maltodekstrin dan tween terhadap aroma minuman serbuk instan sereh. Aroma paling terasa sereh yaitu perlakuan pertama, dikarenakan sedikitnya campuran dalam proses pembuatan ekstrak seperti maltodekstrin dan tween.

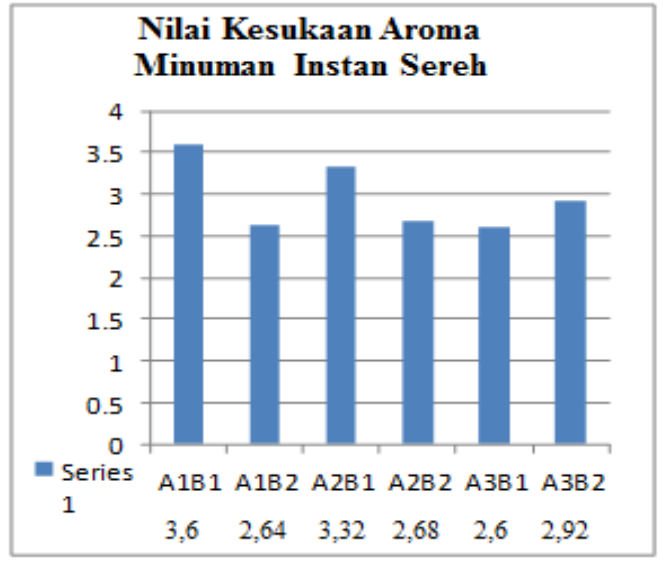

Gambar 2. Grafik tingkat kesukaan panelis terhadap aroma minuman sereh
Tingkat kesukaan terendah oleh panelis diberikan pada minuman serbuk instan sereh dengan konsentrasi maltodekstrin $15 \%$ dan konsentrasi tween $0,3 \%$. Tingkat kesukaan tertinggi oleh panelis diberikan pada minuman serbuk instan sereh dengan konsentrasi maltodekstrin $15 \%$ dan konsentrasi tween $0,4 \%$. Konsentrasi maltodekstrin dan tween terhadap aroma minuman serbuk instan sereh.

\section{Uji organoleptik rasa}

Total rengking penilaian panelis terhadap rasa minuman serbuk instan Sereh akibat pengaruh konsentrasi maltodekstrin dan lama pengeringan yang berbeda berkisar antara 2,52 (tidak suka) dan 3,04 (suka). Tingkat kesukaan terendah oleh panelis diberikan pada minuman serbuk instan sereh dengan konsentrasi maltodekstrin 30\% dan konsentrasi tween 0,4\%. Hal ini karena konsentrasi maltodekstrin dan konsentrasi tween $0,4 \%$. Tingkat kesukaan tertinggi oleh panelis diberikan pada minuman serbuk instan sereh dengan konsentrasi maltodekstrin $20 \%$ dan konsentrasi tween $0,3 \%$. Konsentrasi maltodekstrin dan tween terhadap aroma minuman serbuk instan sereh. Rasa yang paling terasa sereh yaitu A1B1 dikarenakan bahan tambahan yang sedikit sehingga rasanya menjadi lebih terasa sangat pekat.

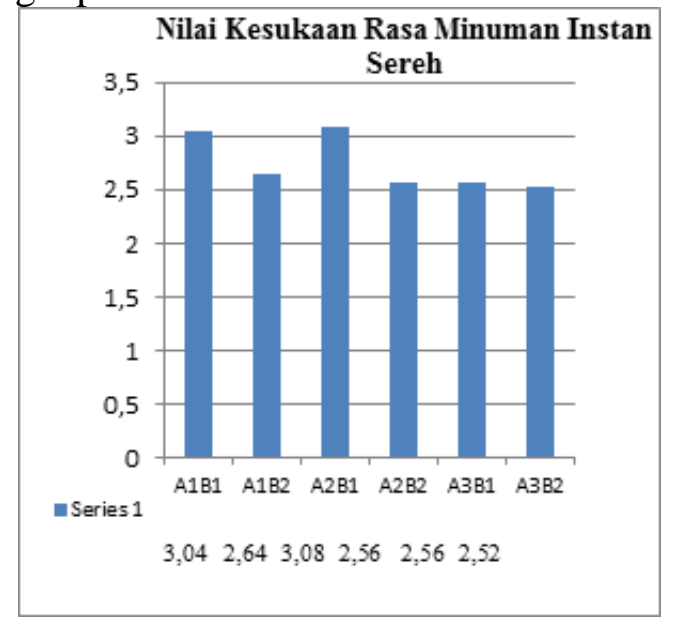

Gambar 3. Grafik tingkat kesukaan panelis terhadap rasa minuman sereh

Tingkat kesukaan terendah oleh panelis diberikan pada minuman serbuk instan sereh dengan konsentrasi maltodekstrin 30\% dan konsentrasi tween $0,4 \%$. Hal ini karena 
konsentrasi maltodekstrin dan konsentrasi tween $0,4 \%$ memiliki rasa yang tidak terasa sereh. Tingkat kesukaan tertinggi oleh panelis diberikan pada minuman serbuk instan sereh dengan konsentrasi maltodekstrin 20\% dan konsentrasi tween $0,3 \%$. Konsentrasi maltodekstrin dan tween terhadap aroma minuman serbuk instan sereh.

\section{Perlakuan terbaik}

Penentuan perlakuan terbaik minuman serbuk instan sereh dilakukan dengan menggunakan metode indeks efektifitas De Garmo (1984) yang dimodifikasi oleh Susrini (2003). Bobot parameter disajikan pada gambar 4. di bawah ini.

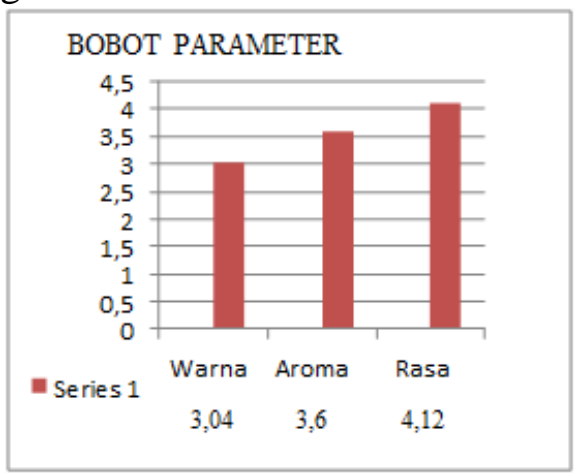

Gambar 4. Bobot parameter dari perlakuan terbaik

Metode yang dilakukan dengan parameter organoleptik dengan perlakuan terbaik A1B1 (maltodekstrin 15\% dan tween $0,3 \%$ ) dengan karakteristrik sebagai berikut warna 3,04 (netral/biasa), aroma 3,6 (netral/biasa) dan rasa 4,12 (netral/biasa). Menurut panelis dengan penambahan bahan pengisi yang rendah dan penambahan bahan pembuih yang rendah membuat rasa dari minuman serbuk instan sereh lebih terasa sereh dan memiliki warna yang lebih menarik.

\section{KESIMPULAN}

Analisa Antioksidan terbaik pada kombinasi perlakuan A2B2 (maltodekstrin $20 \%$ dan tween 0,4\%) dengan nilai 9,3295mg/g. Analisa Kadar Air terbaik pada kombinasi perlakuan A2B2 (maltodekstrin 20\% dan tween 0,4\%) dengan nilai 5,795\%. Analisa Total Padatan Terlarut terbaik pada kombinasi perlakuan A1B1 (maltodekstrin $15 \%$ dan Tween $0,3 \%$ ) dengan nilai 13,5 Brix. \%. Analisa Kadar warna $\mathrm{L}^{+}$terbaik pada kombinasi perlakuan A3B2 (maltodekstrin 30\% dan Tween 0,4\%) dengan nilai 89,775. Analisa Kadar warna $\mathrm{a}^{+}$ terbaik pada kombinasi perlakuan A1B2 (maltodekstrin 15\% dan Tween 0,4\%) dengan nilai 7,875. Analisa Kadar warna $\mathrm{b}^{+}$ terbaik pada kombinasi perlakuan A2B2 (maltodekstrin $20 \%$ dan Tween 0,4\%) dengan nilai 28,725. Perlakuan terbaik adalah A1B1 (maltodekstrin 15\% dan tween $0,3 \%$ ) dengan karakteristrik sebagai berikut warna 3,04 (netral/biasa), aroma 3,6 (netral/biasa) dan rasa 4,12 (netral/biasa).

\section{SARAN}

Perlu adanya penelitian lanjut mengenai pengaruh persentase sereh terhadap maltodekstrin dan tween terhadap kandungan antioksidan minuman serbuk instan sereh dan Penelitian lanjutan mengenai pengaruh suhu dan waktu saat blanching dalam proses pembuatan ekstrak sereh pada pembuatan minuman serbuk instan sereh.

\section{UCAPAN TERIMA KASIH}

Ucapan terima kasih kepada dosen pembimbing dan para dosen ilmu teknologi pangan Universitas Yudharta Pasuruan, serta teman-teman yang ikut memberi saran masukan kepada penulis.

\section{DAFTAR PUSTAKA}

Asiah, N., Sembodo, R., \& Prasetyaningrum, A. (2012). Aplikasi pengeringan dengan metode foam mat drying pada proses pengeringan spriluna. Jurnal Teknologi kimia dan industri, 1(1), 461-467.

Bachtiar, R. (2011). Pembuatan minuman sari kurma (Phoenic dactylifera). Skripsi. Institut Pertanian Bogor. Bogor. 
Farikha, I. N., Anam, C., \& Widowati, E. (2013). Pengaruh jenis dan konsentrasi bahan penstabil alami terhadap karakteristik fisikokimia sari buah naga merah (Hylocereus polyrhizus) selama penyimpanan. Jurnal Teknosains Pangan, 2(1), 3038.

Gumilar, J., Yohana, G. H. R., \& Hidayatulloh, A. (2017). Kemampuan Serbuk Serai (Cymbopogon Citratus) Menekan Peningkatan Total Bakteri Dan Keasaman $(\mathrm{Ph})$ Dendeng Domba Selama Penyimpanan. Jurnal Ilmu Ternak, 17(2), 106-111.

Kusumah, R.A. 2007. Optimasi kecukupan panas melalui pengukuran distribusi dan penetrasi panas pada formulasi minuman sari buah pala (Myristica fragrans houtt). Skripsi.. Institut Pertanian Bogor. Bogor

Muchtadi T.R., Ayutaningwarno F. (2010). Teknologi proses pengolahan pangan.bandung (ID): Alfabeta.

Mulyani, T. Yulistiani dan Nopriyanti M. (2014). Pembuatan bubuk sari buah markisa dengan metode (foam-mat dryig). Jurnal Rekapangan, 8(1), 2238.

Nurhadi, G. (2015). Pengaruh konsentrasi tween 80 terhadap stabilitas fisik obat kumur minyak atsiri herba kemangi (Ocimum americanum L.). Thesis. UIN Syarif Hidayatullah Jakarta.

Olorunnisola, S.K. et al., (2014). Biological properties of lemongrass: $A n$ Overview. International Food Research Journal, 21(2), 455-462

Paramita, I. M. I., Mulyani, S., \& Hartiati, A. (2015). Pengaruh konsentrasi maltodekstrin dan suhu pengeringan terhadap karakteristik bubuk minuman sinom. Jurnal Rekayasa dan Manajemen Agroindustri, 3(2), 58-68.

Permata, D. A., \& Sayuti, K. (2016). Pembuatan minuman serbuk instan dari berbagai bagian tanaman meniran (Phyllanthus niruri). Jurnal
Teknologi Pertanian Andalas, 20(1), 44-49.

Pujimulyani, D. (2009). Teknologi pengolahan sayur-sayuran dan buahbuahan. Yogyakarta: Graha Ilmu.

Putra, S. D. R., Ekawati, L. M. (2013). Kualitas minuman serbuk instan kulit buah manggis (Garcinia mangostana Linn) dengan variasi maltodekstrin dan suhu pemanasan. Jurnal Universitas Atma Jaya Yogyakarta,115.

Ramadhani, D. (2016). Pengaruh konsentrasi maltodekstrin dan putih telur terhadap karakteristik minuman serbuk buah naga merah (Hylocereus polyrhizus). Artikel. Universitas Pasundan Bandung.

Sebayang, E. P. (2014). Pengendalian mutu minyak atsiri sereh wangi (Citronellal oil) di UKM sari murni. Universitas Sebelas Maret Surakarta. diakses tanggal, 24 Juli 2019.

Siagian, H. (2017). Pengaruh perbandingan jumlah gula aren dengan krimer dan persentase maltodekstrin terhadap karakteristik bubuk minuman jahe instan. Skripsi. Universitas Sumatra Utara. Medan.

Susanti, Y. I., \& Putri, W. D. R. (2014). Pembuatan minuman serbuk markisa merah (Passiflora edulis f.edulis sims) (kajian konsentrasi tween 80 dan suhu pengeringan). Jurnal Pangan dan agroindustri, 2(3), 170179.

Tangkeallo, C., \& Widyaningsih, T. D. (2014). Aktivitas antioksidan serbuk minuman instan berbasis miana kajian jenis bahan baku dan penambahan serbuk jahe. Jurnal Pangan dan Agroindustri, 2(4), 278284.

Utomo, D. (2013). Pembuatan serbuk effervescent murbei (Morus alba L.) dengan kajian konsentrasi maltodekstrin dan suhu pengering. Teknologi Pangan : Media Informasi dan komunikasi Ilmiah Teknologi Pertanian, 5(1), 49-69. 
Yuliwaty, S. T., \& Susanto, W. H. (2014). Pengaruh lama pengeringan dan konsentrasi maltodekstrin terhadap karakteristik fisik kimia dan organoleptik minuman instan daun mengkudu (Morinda citrifolia L) . Jurnal Pangan dan Agroindustri, $3(1), 41-52$. 